\title{
Gangguan Ginjal Akut pada Demam Berdarah Dengue
}

\author{
Harun Arrasyd Rydha, Syarifuddin Rauf, Dasril Daud \\ Departemen Ilmu Kesehatan Anak Fakultas Kedokteran Universitas Hasanuddin RS Wahidin \\ Sudirohusodo, Makassar
}

\begin{abstract}
Latar belakang. Demam berdarah dengue (DBD) merupakan masalah kesehatan masyarakat di berbagai bagian dunia, 50 juta orang terinfeksi virus dengue setiap tahun, 500.000 DBD syok (DSS) dengan angka kematian $2,5 \%$.

Tujuan. Mengetahui proses gangguan ginjal akut (GnGA) sebagai komplikasi DBD.

Metode. Penelitian potong lintang pada 86 pasien DBD yang dirawat di RS Wahidin Sudirohusodo, RS Islam Faisal, dan RS Ibnu Sina Makassar, mulai September 2011 sampai Mei 2012. Konfirmasi diagnosis DBD dengan pemeriksaan IgM dan IgG anti virus dengue, dibagi menjadi DSS dan DBD non syok (DBD-NS).

Hasil. Di antara 86 pasien, 37(43.\%) DSS dan 49(57,0\%) DBD-NS. Rerata kreatinin serum dan eKK pasien DBD-NS $1,11 \mathrm{mg} / \mathrm{dl}$ dan $50,35 \mathrm{ml} / \mathrm{men} / 1,73 \mathrm{~m}^{2}$. Rerata kreatinin serum dan eKK pasien DSS 2,48 $\mathrm{mg} / \mathrm{dl}$ dan $20,335 \mathrm{ml} / \mathrm{men} / 1,73 \mathrm{~m}^{2}$; derajat GnGA menurut $p R I F L E$ adalah $p R I F L E-F 36,05 \%$ pada pasien pasien DSS, $p R I F L E-R$ dan- $I$ 17,44\% dan $31,39 \%$ pada pasien DBD-NS. Analisis statistik memperlihatkan rerata kreatinin serum pasien DSS $(2,481 \mathrm{mg} / \mathrm{dl})$ lebih tinggi secara bermakna dibandingkan pasien DBDNS $(1,116 \mathrm{mg} / \mathrm{dl})$, rerata eKK pasien DSS $\left(20,335 \mathrm{ml} / \mathrm{men} / 1,73 \mathrm{~m}^{2}\right)$ lebih rendah dibandingkan DBD-NS $\left(50,351 \mathrm{ml} / \mathrm{men} / 1,73 \mathrm{~m}^{2}\right)$, dan derajat GnGA $p R I F L E-F$ secara bermakna lebih banyak $(36,05 \%)$ pada pasien DSS dan derajat GnGA $p R I F L E-R$ dan $p R I F L E-R-I$ lebih banyak dijumpai pada pasien DBD-NS $(17,44 \%$ dan $31,39 \%)$.

Kesimpulan. Gangguan ginjal akut (GnGA) pada umumnya ditemukan pada kasus DSS maupun DBD-NS. Derajat GnGA yaitu $p R I F L E-F$ ditemukan pada DSS sedangkan GnGA $p R I F L E-R$ dan $p R I F L E-I$ pada DBD-NS. Sari Pediatri 2014;15(5):307-12.
\end{abstract}

Kata Kunci: DBD, gangguan ginjal akut, $p R I F L E$

Alamat korespondensi:

Dr. Harun Arrasyd Rydha, Sp.A. Departemen Ilmu Kesehatan Anak Fakultas Kedokteran Universitas Hasanuddin RS. Wahidin Sudirohusodo, Makassar. HP: 08135522 2000. E-mail: ivan.albar@yahoo.com

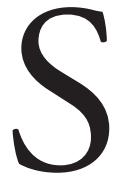
ekitar 50 juta orang terinfeksi virus dengue setiap tahun, 500.000 disertai syok (DSS) dengan angka kematian 2,5\%. ${ }^{1,2}$ Di Asia Tenggara, DBD merupakan penyebab utama morbiditas dan mortalitas anak umur $<15$ tahun yang dirawat di rumah sakit. ${ }^{3}$ Dilaporkan 11,730 pasien 
DBD di Indonesia pada tahun 2006 dengan kematian 1,152 kasus (CR 1,03\%) ${ }^{4}$ dan pada periode yang sama di Sulawesi Selatan dilaporkan 2612 kasus DBD dengan kematian 22 pasien (CFR 0,84\%). ${ }^{5}$ Ganda dan Bombang ${ }^{6}$ melaporkan 1157 pasien DBD dari bulan Januari 1998 sampai dengan Desember 2005 di RS Dr. Wahidin Sudirohusodo/Bagian Ilmu Kesehatan Anak FK UNHAS Makassar, terdiri dari 698 orang (60\%) DBD tanpa syok (DBD-NS) dan 459 orang (40\%) DBD dengan syok, meninggal 88 pasien DSS $(19 \%)$.

Gangguan ginjal akut (GnGA) yang sebelumnya dikenal dengan istilah gagal ginjal akut adalah penurunan fungsi ginjal mendadak yang ditandai oleh peningkatan reversibel kreatinin serum dan produk limbah nitrogen serta ketidakmampuan ginjal mengendalikan gangguan keseimbangan cairan, elektrolit, dan asam-basa. ${ }^{7-11}$ Diagnosis GnGA pada pasien dewasa ditegakkan menggunakan kriteria RIFLE (risk, injury, failure, loss, end stage) dan pada tahun 2007 dibuat modifikasi kriteria RIFLE untuk anak (pediatric RIFLE / pRIFLE)..$^{-, 9,12}$

Dari latar belakang tersebut, dirasakan perlu dilakukan penelitian GnGA pada pasien DBD berdasarkan kriteria $p R I F L E$.

\section{Metode}

Penelitian potong lintang dilakukan mulai dari bulan September 2011 sampai Mei 2012 pada pasien DBD berumur1-15 tahun yang dirawat di RS Wahidin Sudirohusodo, RSI Faisal, dan RS Ibnu Sina, Makassar. Kriteria diagnostik DBD ditegakkan dengan kriteria WHO $1997^{14}$ yang dikonfirmasi dengan pemeriksaan serologis IgM dan IgG antivirus dengue. Kriteria inklusi adalah pasien DBD berumur 1-15 tahun dan sudah menandatangani informed consent. Kriteria eksklusi adalah apabila pasien sudah diberikan resusitasi cairan sebelum masuk rumah sakit disertai penyakit penyerta, seperti gagal jantung, penyakit ginjal, pneumonia, penyakit susunan syaraf pusat, diare dehidrasi, dan gizi buruk. Subjek yang memenuhi kriteria penelitian selanjutnya dikelompokkan ke dalam kelompok pasien DBD-NS dan pasien DSS. Pasien dengan gagal sirkulasi, yaitu tekanan nadi $<20 \mathrm{mmHg}$, hipotensi, atau syok dikelompokkan sebagai pasien DSS (DBD derajat III atau IV) sedangkan pasien yang tidak disertai gagal sirkulasi dikelompokkan sebagai pasien DBD-NS
(DBD derajat I atau II). ${ }^{13}$

Untuk menentukan GnGA dilakukan pemeriksaan kreatinin serum dan estimasi klirens kreatinin menggunakan rumus Schwarzt. ${ }^{10-12}$ Pasien yang memenuhi kriteria $p R I F L E$ dikelompokkan sebagai pasien GnGA dan ditentukan derajat keparahan GnGA menggunakan krieria $p R I F L E$ sebagai tingkat pRIFLE-risk $(R)$ apabila estimasi klirens kreatinin (eKK) menurun $>25 \%$ nilai dasar eKK sesuai usia, pRIFLE-injury (I) apabila penurunan eKK $>50 \%$, dan pRIFLE-failure $(F)$ apabila penurunan eKK $>75 \%$ dari nilai dasar sesuai usia. ${ }^{9-12}$ Nilai dasar eKK sebaiknya ditentukan menggunakan rumus Schwartz dari nilai kreatinin serum yang diperiksa 3 bulan terakhir sebelum masuk rumah sakit. Namun, apabila tidak ada data nilai kreatinin serum maka digunakan nilai dasar $120 \mathrm{ml} / \mathrm{men} / 1.73 \mathrm{~m}^{2} .^{11}$ Penelitian ini telah disetujui oleh Komite Medis Penelitian Biomedis Fakultas Kedokteran UNHAS. Analisis statistik menggunakan data deskriptif dalam bentuk rerata, simpang baku, median, maksimum, minimum, frekuensi, dan prosentase yang sesuai. Perbandingan GnGA antara pasien DBD-NS dan DSS digunakan uji student $t$ dan Mann-Whitney $U$ bagi subjek dengan distribusi normal dan tidak normal sedangkan uji $\mathrm{X}^{2}$ digunakan untuk membandingkan variabel dengan nilai nominal antara dua kelompok tidak berpasangan, meliputi proporsi jenis kelamin, satus gizi, dan derajat GnGA pasien DBD-NS dan DSS. Nilai $\mathrm{p}<0,05$ dianggap bermakna secara statistik bagi semua uji analisis.

\section{Hasil}

Delapanpuluh enam pasien DBD anak memenuhi kriteria penelitian, terdiri dari 37 (43\%) DSS dan 49 (57\%) DBD-NS, $41(47,7 \%)$ anak laki-laki dan 45 $(52,3 \%)$ anak perempuan dengan rerata umur 7,44 tahun, umur terendah 1,41 tahun dan tertinggi 14 tahun. Jumlah pasien DBD gizi baik 50 orang $(58,1 \%)$ dan gizi kurang 36 orang $(41,9 \%)$. Rerata kadar kreatinin serum $1,70 \mathrm{mg} / \mathrm{l}$ dan rerata eKK $37,43 \mathrm{ml} /$ menit $/ 1,73 \mathrm{~m}^{2}$. Distribusi derajat GnGA pasien DBD menurut kriteria $p R I F L E$ yaitu $p R I F L E-R$ sebesar 18,60\%, pRIFLE-I 37,20\%, dan pRIFLE-F 40,7-\%.

Rerata nilai kreatinin serum pasien DBD-NS adalah $1,12 \mathrm{mg} / \mathrm{dl}$ (normal), dan pasien DSS 2,48 $\mathrm{mg} / \mathrm{dl}$. Dari hasil analisis statistik terdapat perbedaan bermakna antara pasien DSS dan DBD-NS ( $p=0,000$ 
Tabel 1. Karakteristik dasar 86 pasien DBD

\begin{tabular}{lc}
\hline Karakteristik subjek & $\mathrm{n}(\%)$ \\
\hline Jenin kelamin & \\
$\quad$ Lelaki & \\
$\quad$ Perempuan & $(47,7)$ \\
Umur (tahun) & $45(52,3)$ \\
$\quad$ Rerata \pm SB & \\
Status gizi & $7,44 \pm 3,32$ \\
$\quad$ Baik & \\
$\quad$ Kurang & $50(58,1)$ \\
Derajat DBD & $36(41,9)$ \\
$\quad$ DSS & \\
DBD-NS & $37(43,0)$ \\
Kreatinin serum (mg/dl) & $49(57,0)$ \\
$\quad$ Rerata \pm SB & \\
Estimasi klirens kreatinin $\left(\mathrm{ml} / 1,73 \mathrm{~m}^{2} / \mathrm{m}\right)$ \\
$\quad$ Rerata \pm SB & $1,70 \pm 0,85$ \\
GnGA & $36,82 \pm 22,85$ \\
$\quad$ Normal & \\
$p R I F L E-R$ & $3(3,5)$ \\
pRIFLE-I & $15(17,4)$ \\
$p R I F L E-F$ & $33(38,4)$ \\
\end{tabular}

$\left.\mathrm{ml} / 1,73 \mathrm{~m}^{2} / \mathrm{men}\right)(\mathrm{p}=0,000<0,001)$. Jadi LFG pasien DSS berkurang abnormal lebih rendah dibandingkan pasien DBD-NS (Tabel 2).

Derajat GnGA $p$ RIFLE-F lebih banyak ditemukan pada pasien DSS (36,05\%) daripada pasien DBD-NS (4,65\%); sedangkan derajat GnGA $p R I F L E-R$ dan pRIFLE-I lebih banyak ditemukan pada pasien DBDNS (1517,4\% dan 31,4\%) dibandingkan dengan pasien DSS (1,16\% dan 5,81\%). Hasil pengujian statistik menunjukkan perbedaan bermakna derajat GnGA menurut $p$ RIFLE di antara pasien DBD-NS dan DSS $(\mathrm{p}=0,000<0,001)$. Hal tersebut menunjukkan GnGA yang berat lebih banyak dialami pasien DSS (Tabel 3).

\section{Pembahasan}

Demam berdarah dengue dengan syok sering kali menimbulkan kegawatan pada anak dan menjadi salah satu penyebab kematian. ${ }^{14-16}$ Angka kematian DBD di beberapa negara sekitar 5\%, terbanyak pada usia

Tabel 2. Kreatinin serum dan estimasi klirens kreatinin pasien DBD

\begin{tabular}{lcc}
\hline Variabel & $\begin{array}{c}\text { DBD-NS } \\
\mathrm{n}(49)\end{array}$ & $\begin{array}{c}\text { DSS } \\
\mathrm{n}(37)\end{array}$ \\
\hline Kadar kreatinin serum $(\mathrm{mg} / \mathrm{dl})$ rerata \pm SB & $1,12 \pm 0,37$ & $2,48 \pm 0,65$ \\
Nilai ekk $\left(\mathrm{ml} / 1,73 \mathrm{~m}^{2} /\right.$ menit $)$ & $48,99 \pm 21,98$ & $20,33 \pm 8,48$ \\
\hline
\end{tabular}

Rerata \pm SB

$\begin{array}{llr}\text { Mann-Whitney } U \text { 65 } & \mathrm{Z}=-7.340 & \mathrm{p}=0,000 \\ \text { Mann-Whitney } U 130.500 & \mathrm{Z}=-6.769 & \mathrm{p}=0,000\end{array}$

Tabel 3. Derajat GnGA menurut kriteria pRIFLE pada DBD

\begin{tabular}{lccc}
\hline & \multicolumn{3}{c}{ Pasien } \\
\cline { 2 - 4 } Derajat pRIFLE & DBD-NS & DSS & Total \\
& $\mathrm{n}(\%)$ & 0 & $\mathrm{n}(\%)$ \\
\hline N-normal & $3(3,5)$ & 0 & $3(3,5)$ \\
R-risk & $15(16,27)$ & $4(15,63)$ & $3(18,6)$ \\
I-injury & $29(32,50)$ & $31(88,57)$ & $35(37,2)$ \\
F-failure & $4(4,60)$ & $37(43)$ & $86(100)$ \\
\hline Total & $49(57)$ & &
\end{tabular}

$<0,001)$. Dengan kata lain, fungsi ginjal pasien DSS menurun secara bermakna dibandingkan pasien DBD-NS (Tabel 2). Rerata nilai eKK pasien DSS lebih rendah $\left(20,33 \mathrm{ml} / 1,73 \mathrm{~m}^{2} / \mathrm{men}\right)$ secara bermakna dibandingkan rerata nilai eKK pasien DBD-NS $(50,40$ anak. ${ }^{2} \mathrm{Di}$ Indonesia, insiden DBD tertinggi dilaporkan selama tahun 1987 dengan jumlah kasus 22760 dan 1039 pasien meninggal (CFR 4,6\%). ${ }^{16}$ Banyak peneliti melaporkan kejadian GnGA pada pasien DBD, antara lain peningkatan kreatinin serum pada $43 \%$ kasus 
DBD di Thailand, ${ }^{17}$ azotemia transien dan GnGA yang ditemukan pada pasien DBD, 1,6\% GnGA pada DBD di Kolumbia, ${ }^{17}$ 4,9\% GnGA pada pasien dewasa dengan DSS di Cina, ${ }^{18}$ dan 33,3\% kejadian GnGA pada pasien DBD yang meninggal di Thailand. ${ }^{19}$ Kejadian GnGA pada pasien DBD dihubungkan dengan hipoperfusi ginjal akibat hipovolemia karena syok, hemolisis, atau rabdomiolisis. Hipoperfusi ginjal pada pasien DBD mengakibatkan LFG menurun yang ditandai oleh oligouria dan peningkatan serum kreatinin sebagai manifestasi GnGA prarenal. 12,20-24

Gangguan ginjal akut prarenal mengacu pada penurunan laju filtrasi glomerulus (LFG) yang terjadi secara tiba-tiba oleh karena perfusi ginjal yang tidak adekuat (hipoperfusi ginjal), merupakan 55\%-60\% GnGA. ${ }^{37,4,22}$ Apabila penurunan volume plasma $<10 \%$ dan rerata tekanan arteri turun $<80 \mathrm{mmHg}$ maka akan terjadi penurunan LFG yang bermanifestasi sebagai GnGA. Hipoperfusi ginjal ditemukan pada 40\%$80 \%$ GnGA prarenal dan bila dikoreksi segera akan refersibel. Penyebab GnGA prarenal melipui setiap penyebab volume sirkulasi darah berkurang (DBD, perdarahan saluran cerna, luka bakar, diare), sekuestrasi volume darah (pankreatitis, peritonitis, rabdomiolisis), atau volume efektif darah arteri berkurang (DSS, syok kardiogenik, sepsis). Perfusi ginjal dipengaruhi juga oleh reduksi curah jantung karena vasodilatasi perifer (sepsis, obat) atau vasokonstriksi ginjal berat (gagal jantung berat, sindrom hepatorenal, obatobat seperti NSAIDs). Hipovolemia arteri efektif menyebabkan penurunan rerata tekanan arteri sehingga memicu respon neural dan humoral yang mengakibatkan aktivasi saraf simpatik dan sistem renin-angiotensin-aldosterone dan pelepasan $\mathrm{ADH}$. Laju filtrasi glomerulus dipertahankan oleh relaksasi arteriol aferen yang dimediasi oleh prostaglandin dan konstriksi arteriol eferen yang dimediasi oleh angiotensin II. Apabila rerata tekanan arteri turun $<80 \mathrm{mmHg}$ maka terjadi penurunan LFG, sedangkan hipoperfusi berkepanjangan menyebabkan ATN. 3,14,20-22

Data penelitian menunjukkan bahwa rerata kadar kreatinin serum pasien DSS lebih tinggi dibandingkan dengan pasien DBD-NS, sedangkan rerata nilai eKK pasien DSS lebih rendah dibandingkan dengan DBDNS. Hal tersebut berarti bahwa gangguan fungsi ginjal pada pasien DSS lebih sering dijumpai apabila dibandingkan dengan pasien DBD-NS karena syok hipovolemik terjadi pada DSS atau DBD derajat III (initial hypovolemic shock) dan IV (profound shock). Hal yang sama juga dilaporkan oleh Méndez dan González ${ }^{17}$ bahwa manifestasi klinis abnormal ditemukan pada 7\% kasus DSS. Hasil penelitian Chaivisuth ${ }^{25}$ pada anak Thai $<14$ tahun menunjukan GnGA yang ditandai dengan peningkatan kreatinin serum ditemukan baik pada demam dengue $(51,1 \%)$ maupun DBD (60,9\%). Hal tersebut juga ditemukan dalam penelitian pada 4 pasien DBD-NS $(11,43 \%)$ mengalami GnGA pRIFLE-F. Hal tersebut berarti bahwa selain hipoperfusi ginjal yang disebabkan oleh hipovolemia sampai syok pada DBD memicu terjadinya GnGA, terdapat juga mekanisme lain yang bertanggung jawab terhadap kejadian GnGA pada pasien DBD. ${ }^{16}$ Beberapa peneliti menyimpulkan bahwa mekanisme imunologik akibat virus dengue memicu manifestasi $\mathrm{DBD}$, juga secara langsung mengakibatkan manifestasi GnGA akibat cedera langsung pada glomerulus pasien DBD. Laporan dari India Nair $\mathrm{dkk}^{19}$ dan Lima $\mathrm{dkk}^{15}$ menemukan manifestasi GnGA pada pasien DBD bukan disebabkan oleh syok, hemolisis, atau rabdomiolisis, atau obat nefrotoksis, tetapi akibat cedera langung virus dengue yang dimediasi oleh reaksi antigen-antibod pada glomerulus. Hal tersebut terbukti dengan ditemukannya penurunan komplemen C3 dan C4 sebagai akibat immune-mediated acute glomerular injury. Hal serupa juga dilaporkan oleh Futrakul $\mathrm{dkk}^{26}$ di Thailand yang menemukan peningkatan kreatinin serum pada $43 \%$ dan penurunan komplemen C3 pada 82\% kasus DBD. Pada biopsi 20 kasus DBD ditemukan hipertrofi dan hiperplasia sel-sel mesangial dan endotel, sel mirip monosit pada lumen kapiler glomerulus, penebalan fokal membran basalis glomerulus, deposit IgG, IgM, dan C3 di sepanjang dinding arteriol dan kapiler glomerulus dua minggu sesudah gejala klinik menghilang. Hal yang sama juga dilaporkan oleh Jessy $\mathrm{dkk}^{27}$ penemuan antigen virus dengue pada sel tubulus ginjal pasien DBD-NS dan DSS. Pada penelitian tikus yang diinokulasi dengan virus dengue ditemukan bukti bahwa virus dengue dapat meninduksi glomerulopati akibat terjadinya diffuse proliferative glomerular injury, dilatasi volume glomerulus, peningkatan sel-sel mesangial dan endotel kapiler, serta deposit IgM di sepanjang glomerulus. Dari penelitian ini, disimpulkan bahwa autoimmunemediated mechanisms terlibat dalam patogenesis GnGA pada DBD.

Hasil penelitian kami memperlihatkan derajat GnGA menurut kriteria $p R I F L E-F$ lebih banyak ditemukan pada pasien DSS daripada pasien DBD- 
NS, sedangkan $p R I F L E-R$ dan $p R I F L E-I$ lebih banyak ditemukan pada pasien DBD-NS dibandingkan dengan pasien DSS. Ditemukan pula perbedaan derajat GnGA menurut kriteria $p R I F L E$ di antara pasien DSS dan DBD-NS. Hasil serupa juga dilaporkan oleh Laoprasopwattana $\mathrm{dkk}^{28}$ bahwa GnGA pada pasien DBD anak Thailand $<15$ tahun sebesar $0,9 \%$ dengan kematian tinggi pada DBD derajat IV. Maka diagnosis dini dan tata laksana akurat DSS akan mencegah syok berkepanjangan dan berulang, serta mengurangi mortalitas anak dengan DSS. ${ }^{28,29}$

Keterbatasan dari penelitian kami adalah penelitian potong lintang sehingga tidak dapat menentukan kadar kreatinin serum, nilai eKK, dan nilai $p R I F L E$ serial sesudah tata laksana pasien atau saat penyembuhan. Oleh karena itu, dianjurkan pemeriksaan serial kreatinin serum dan urinalsis pada setiap pasein DBD agar dapat menentukan GnGA disebabkan oleh syok hipovolemik dan atau acute glomerular injury akibat cedera langsung virus dengue melalui mekanisme imunologik.

\section{Kesimpulan}

Gangguan ginjal akut lebih sering pada pasien DSS daripada pasien DBD-NS. Kami menyarankan untuk melakukan pemeriksaan serial kadar kreatinin serum dan eKK pada semua pasien DBD untuk menilai derajat GnGA menurut kriteria $p R I F L E$ saat masuk rumah sakit dan pemeriksaan ulangan kreatinin serum dan eKK dalam perjalanan penyakit dan saat pasien pulang. Kriteria $p R I F L E$ seyogyanya dimasukkan dalam acuan tatalaksana pasien DBD anak untuk mencegah dan mengurangi angka kematian DBD. Perlu dipertimbangkan pemberian infus pada setiap pasien terbukti DBD-NS untuk pencegahan dini GnGA.

\section{Daftar pustaka}

1. Nguyen TH, Nguyen TL, Huan YL. Association between Sex, nutritional Status, severity of dengue hemorrhagic fever, and immune status in infants with dengue hemorrhagic fever. Am J Trop. Med Hyg 2005;72:370-4.

2. Kamath SR, Ranjit S. Clinical feature, complications and atypical manifestations of children with severe forms of dengue hemorrhagic fever in South India. Indian J
Pediatr 2006;73:889-95

3. Gubler DJ. Dengue and dengue hemorrhagic fever. Clinical microbiology reviews. (Diunduh 12 Februari 2008). Didapat dari:http://www.pubmedcentral.nih.govmed.edu/.

4. Samhadi SH. Perang melawan nyamuk. Kompas 3 Februari 2007; h. 33.

5. Anwar M, Tulang T, Aruh S. Profil kesehatan provinsi Sulawesi Selatan 2002. Makassar: Dinkes Provinsi, Sulawesi Selatan, 2003.

6. Ganda IJ, Bombang H. Morbiditas dan mortalitas sindrom syok dengue di Pediatric Intensive Care Unit (PICU) Bagian Ilmu Kesehatan Anak RS dr. Wahidin Sudirohusodo Makassar Januari 1998 - Desember 2005. J Medik Nusantara 2005;26:244-50.

7. Andreoli SP. Acute kidney injury in children. Pediatr Nephrol 2009;24:253-63

8. Mak RH. Acute kidney injury in children: the dawn of a new era. Pediatr Nephrol 2008;23:2147-9.

9. Zappitelli M, Parikh CR, Ackan-Arikan A, Washburn KK, Moffet BS, Goldsetin SL . Ascertainment and epidemiology of acute kidneyiInjury varies with definition interpretation. Clin J Am Soc Nephrol 2008;3:948-54.

10. Laine J. Acute renal failure presentation. Dalam: European Society for Paediatric Nephrology. Ed Cochat P; 2002.h.322-4.

11. Palmieri T, Lavrentieva A, Greenhalgh D. An assessment of acute kidney injury with modified RIFLE criteria in pediatric patients with severe burns. Intensive Care Med 2009;35:2125-212.

12. Mehta RL, Kellum JA, Shah SV, Molitoris BA, Ronco C, Warnock DG, Levin A. Acute kidney injury network: report of an initiative to improve outcomes in acute kidney injury. Crit Care 2007;11;31.

13. Directorate General of Health Services. Investigation and controls of outbreaks dengue fever and dengue hemorrhagic fever. (Diunduh 15 Februari 2008) Didapat dari:http://www.nicd.org/Dengue.asp.

14. Hadinegoro SRH, Satari HI. Demam berdarah dengue. Naskah lengkap pelatihan bagi pelatih dokter spesialis anak dan dokter spesialis penyakit dalam tata laksana kasus DBD. Jakarta: Balai Penerbit FKUI; 2005.

15. Lima EQ, Gorayeb FS, Zanin JR, Nogueria ML, Ramalho HJ, Burdmann EA. Dengue haemorrhagic fever-induced acute kidney injury without hypotension, haemolysis or rhabdomyolysis. Nephrol Dial Transplant 2007;22:3322-6.

16. Soegijanto S. Aspek imunologi penyakit demam ber- 
darah dengue. Edisi 2. Surabaya:Airlangga Univesity Press;2006.

17. Méndez A, González G. Abnormal clinical manifestations of dengue hemorrhagic fever in children. Biomedica 2006;26:61-70.

18. Lee IK, LIU JW, Yang KD. Clinical characteristics and risk factors for concurrent bacteremia in adults with dengue hemorrhagic fever. MJ Trop Med Hyg 2005;72:221-6.

19. Nair R V, Unnikrishnan D, Satish B, Sahdulla MI. Acute renal failire in dengue fever in the absence of bleeding manifestations or shock. Infec Dis in Clinical Practice 2005; 13:3;142-3.

20. McKiernan CA, Lieberman SA. Circulatory shock in children: an overview. Pediatr Rev 2005;26:451-9.

21. Mackway K. Advance pediatric life support. Shock: in the practical approach. Advance Life Support Group. Edisi ke-2. London: BMG Publisher;1993.

22. Schierhout G, Roberts I. Fluid resuscitation with colloid or crystalloid solutions in critically III patients: A systematic review of randomised trials. BMJ 1998;316:961-4.

23. Azis AA. Renjatan hipovolemik pada anak. Naskah Lengkap: "Hot Topics in Pediatrcis" Continuing education IKA XXXV dan Kapita Selekta IKA Anak IV. Hotel JW Marriot, Surabaya 3-4 September2005.

24. Birsin Z. Application of the new classification criteria of the acute kidney injury. Pediatr Nephrol 2009:24:137984.

25. Chaivisuth A. Renal involvement in dengue infection. Thai Pediatr J 2005;1:12:3.

26. Futrakul P, Posyhachinda V, Mitrakul C, Kun- Anake C, Boonpucknavig V, Boonpucknavig S, et al. Renal involvement and reticulo-endothelial-system clearance in dengue hemorrhagic fever. J Med Assoc Thai 1973;56:33-9.

27. Jessy K, Fong MY, devi S, Lam SK, Wong KT. Localization of dengue virus in naturally infected human tissues, by immunohistochemistry and in-situ hybridization. J Infect Dis 2004;189:1411-8

28. Laoprasopwattana K, Pruerkparest P, Dissaneewate P, Geater A, Vachcanichasong P. Outcome of dengue hemorrhagic fever-caused acute kidney injury in Thai children. J Pediatr 2010;157:303-9.

29. Kuo, MC, Lu PL, Chang JM, Lin MY, Tsai JJ, Chen YH, Chang K, Chen HC, Hwang SJ. Impact of renal failure on the outcome of dengue viral infection.Clin J Am Soc Nephrol 2008;3:1350-56. 